\title{
Endoscopic reversal of vertical banded gastroplasty: a novel use of electroincision
}

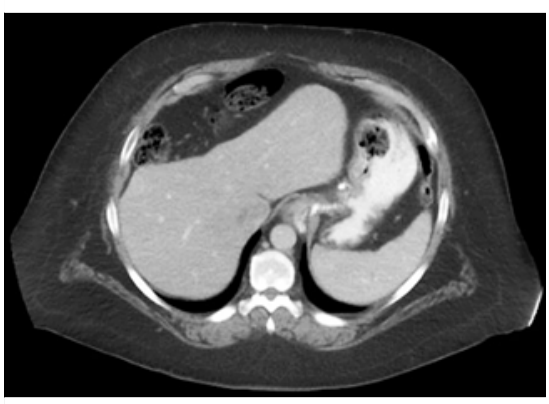

- Fig. 1 Computed tomography demonstrated postoperative changes to the gastroesophageal junction and a hiatal hernia, but no obstruction.

Vertical banded gastroplasty (VBG) was introduced in 1982 as a restrictive form of weight loss surgery through the creation of a pouch using a vertical staple line and outlet restriction with a silastic band [1]. However, the popularity of VBG has waned due to high adverse event rates and the need for surgical revision [2]. We present the case of an endoscopic reversal of a VBG using electroincision ( $>$ Video 1).

A 49-year-old woman with a history of VBG presented with nausea, episodic vomiting, and dysphagia. A computed tomography scan revealed no signs of obstruction ( $>$ Fig. 1). Upper endoscopy demonstrated a large gastrogastric fistula at the staple line with the silastic band eroding into the lumen ( $\triangleright$ Fig. 2 ). Between the gastrogastric fistula and the eroded band, there was a septum of gastric tissue. The tissue pedicles holding the silastic band were incised using a endoscopic submucosal dissection knife, and the band was removed ( $\mathbf{F i g} . \mathbf{3}$ a). The decision was made to reverse the VBG given the patient's symptoms and that the size of the gastrogastric fistula precluded successful endoscopic closure. The gastric septum was then divided ( $\triangleright$ Fig.3b). Hemoclips were placed in areas of mild bleeding.

Repeat endoscopic examination 2 months later revealed a healed resection

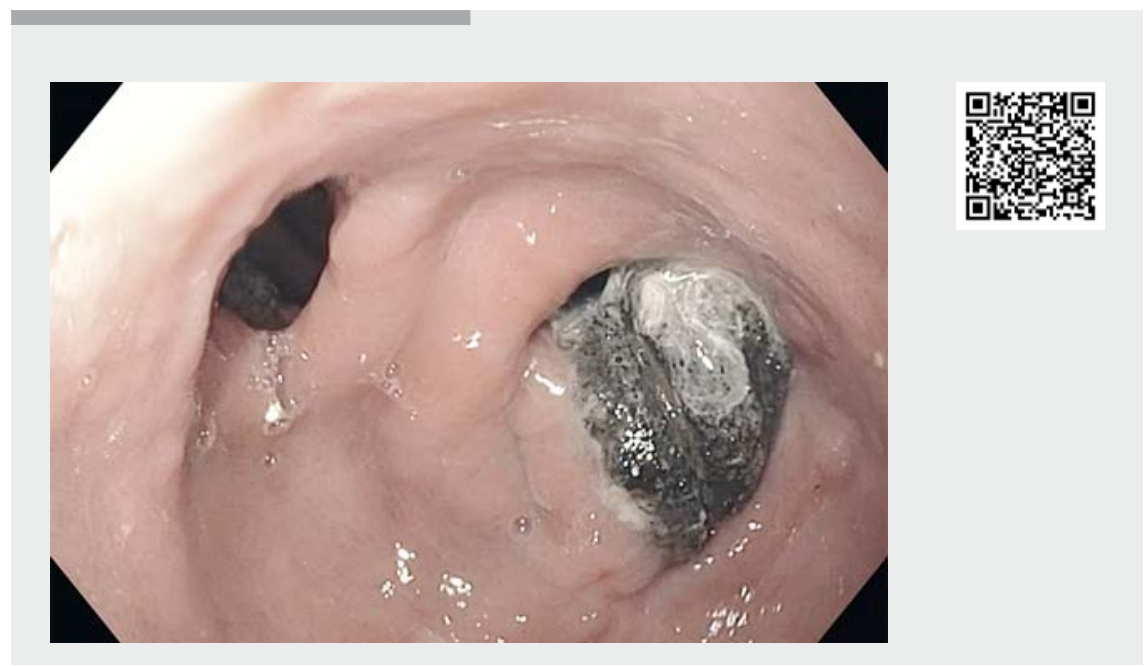

Video 1 Endoscopic reversal of a vertical banded gastroplasty using electroincision.
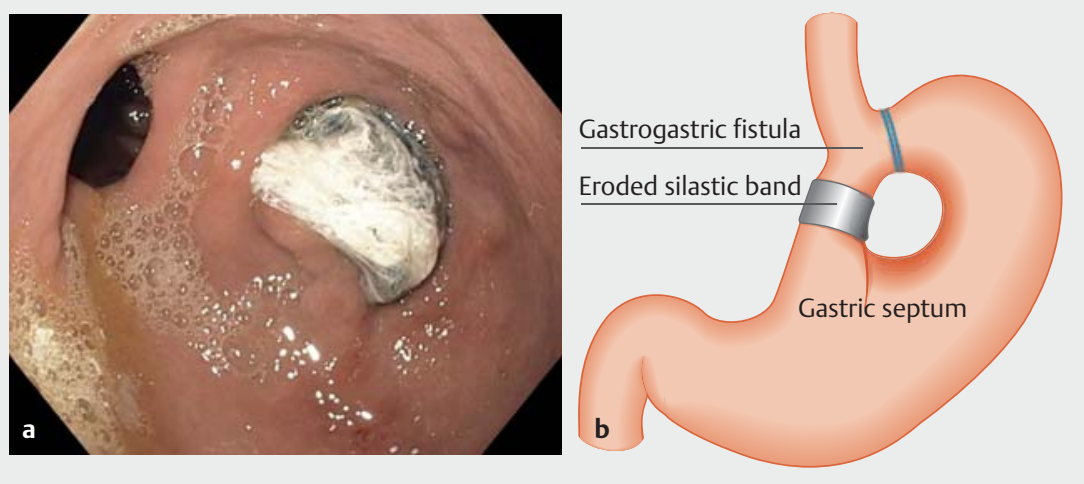

- Fig. 2 Endoscopic findings. a Endoscopy revealed an eroded silastic band on the right and a gastrogastric fistula on the left. $\mathbf{b}$ Diagram of the endoscopic findings in relationship to surgical anatomy.

site with complete reversal of her prior VBG anatomy ( $>$ Fig. 4 ). The patient had complete resolution of all symptoms.

VBGs are associated with high rates of long-term failure due to band erosions, gastric outlet stenosis, and inadequate weight loss [3]. Specifically, band erosions may occur after $1 \%-3 \%$ of VBGs [4]. Methods for removal of eroded bands include the use of Nd:YAG laser, electroincision, and electrosurgical scissors [5]. In our case, we used electroinci- sion to remove the eroded band and also reverse the $\mathrm{VBG}$, resulting in durable symptom control. In conclusion, endoscopic reversal of VBG can be considered in patients with similar presentations.

Endoscopy_UCTN_Code_CPL_1AM_2AF

\section{Competing interests}

Ryan Law: Olympus America-Consultant. 

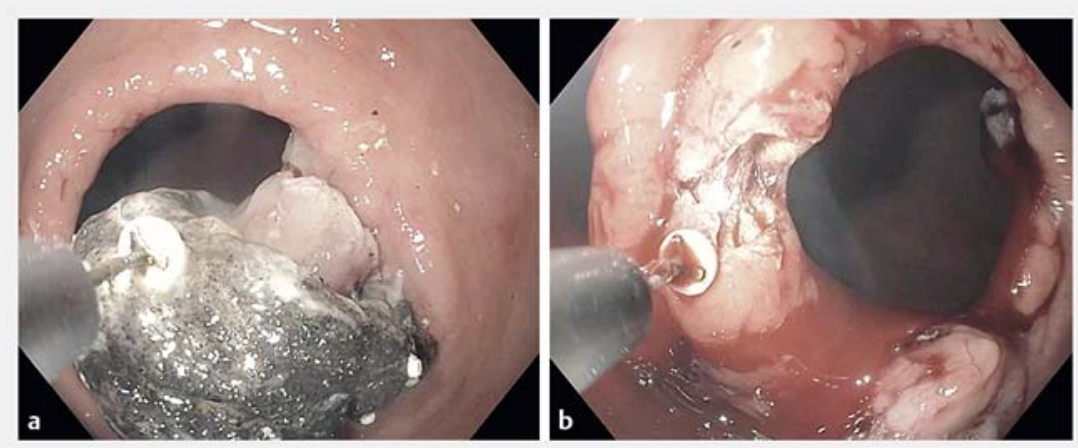

- Fig. 3 Endoscopic treatment using an electroincision knife. a The eroded silastic band was removed by excising the supporting tissue pedicles using an electroincision knife. b Division of the gastrogastric fistula using an electroincision knife.

The authors

\section{Jessica X. Yu, Arpan Patel, Ryan Law}

Division of Gastroenterology and Hepatology, University of Michigan, Ann Arbor, Michigan, United States

\section{Corresponding author}

Jessica X. Yu, MD, MS

Division of Gastroenterology and Hepatology, University of Michigan, 1500 E. Medical Center Dr., 3912 Taubman Center, Ann Arbor, MI 48109-5362, United States

Fax: +1-734-936-7392

jxyu@umich.edu

\section{References}

[1] Mason EE. Vertical banded gastroplasty for obesity. Arch Surg 1982; 117: 701-706

[2] Marsk R, Jonas E, Gartzios H et al. High revision rates after laparoscopic vertical banded gastroplasty. Surg Obes Relat Dis 2009; 5 : 94-98

[3] Hjorth S, Näslund I, Andersson-Assarsson JC et al. Reoperations after bariatric surgery in 26 years of follow-up of the Swedish Obese Subjects study. JAMA Surg 2019; 154: 319 326

[4] Fobi M, Lee H, Igwe D et al. Band erosion: incidence, etiology, management and outcome after banded vertical gastric bypass. Obes Surg 2001; 11: 699-707

[5] Evans JA, Williams NN, Chan EP et al. Endoscopic removal of eroded bands in vertical banded gastroplasty: a novel use of endoscopic scissors (with video). Gastrointest Endosc 2006; 64: 801-804

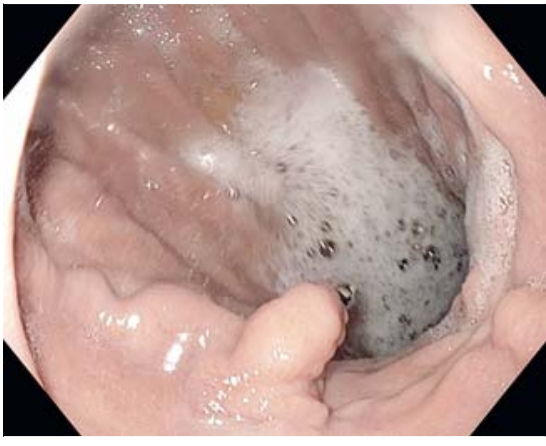

- Fig. 4 Repeat endoscopy at 2 months post-procedure demonstrated reversed vertical banded gastroplasty anatomy.

Bibliography

DOI https://doi.org/10.1055/a-0934-5301

Published online: 1.7.2019

Endoscopy 2019; 51: E360-E361

(c) Georg Thieme Verlag KG

Stuttgart · New York

ISSN 0013-726X

\section{ENDOSCOPY E-VIDEOS}

https://eref.thieme.de/e-videos

口回 Endoscopy E-Videos is a free access online section, reporting 向触: on interesting cases and new techniques in gastroenterological endoscopy. All papers include a high quality video and all contributions are freely accessible online.

This section has its own submission website at https://mc.manuscriptcentral.com/e-videos 